\title{
Microbial Activity during Composting and Plant Growth Impact: A Review
}

\author{
Pritam Priyadarshi Rath $^{1}$ (D), Kajari Das ${ }^{2}$ (D) and Sumitra Pattanaik ${ }^{1 *}$ (iD \\ ${ }^{1}$ Department of Community Medicine, IMS \& SUM Hospital, Siksha O Anusandhan deemed to be University, \\ Bhubaneswar - 751003 , Odisha, India. \\ ${ }^{2}$ Department of Biotechnology, College of Basic Science and Humanities, Odisha University of Agriculture and \\ Technology, Bhubaneswar - 751 003, Odisha, India.
}

\begin{abstract}
Replacing harmful chemical pesticides with compost extracts is steadily gaining attention, offering an effective way for plant growth enhancement and disease management. Food waste has been a major issue globally due to its negative effects on the environment and human health. The methane and other harmful organisms released from the untreated waste have been identified as causes of this issue. Soil bacteria impart a very important role in biogeochemical cycles. The interactions between plants and bacteria in the rhizosphere are some of the factors that determine the health and fertility of the soil. Free-living soil bacteria are known to promote plant growth through colonizing the plant root. PGPR (Plant Growth Promoting Rhizobacteria) inoculants in compost are being commercialized as they help in the improvement of crop growth yield and provide safeguard and resistance to crops from disease. Our focus is to understand the mechanism of this natural, wet waste recycling process and implementation of a sustainable operative adaptation with microbial association to ameliorate the waste recycling system.
\end{abstract}

Keywords: Microbial activity, Composting and Plant, PGPR, Microbial ecology, Green waste

\footnotetext{
*Correspondence: sumitrapattanaik@soa.ac.in

(Received: November 9, 2021; accepted: January 4, 2022)

Citation: Rath PP, Das K, Pattanaik S. Microbial Activity during Composting and Plant Growth Impact: A Review. J Pure App/ Microbiol. 2022;16(1):63-73. doi: 10.22207/JPAM.16.1.53

(C) The Author(s) 2022. Open Access. This article is distributed under the terms of the Creative Commons Attribution 4.0 International License which permits unrestricted use, sharing, distribution, and reproduction in any medium, provided you give appropriate credit to the original author(s) and the source, provide a link to the Creative Commons license, and indicate if changes were made.
} 


\section{INTRODUCTION}

Generally, composting means the controlled breaking down of the degradable organic materials to a stable product by microorganisms. During this process, the major bulk of organic waste is reduced by volume and is directly used by plants through recycling. This is the noblest way of reducing the environmental and economic costs where the fundamental objective is to recirculate and reuse nutrient solutions. Composting results in a very low quantity of nitrogen, phosphorus, potassium as well as macro and micronutrients as compared to the chemical fertilizers. It is also a fact that plants can fulfil their requirement of nutrients immediately from chemical fertilizers, but their negative effect outweighs their positive effect on plants and the environment. Chemical fertilizers are the major cause of greenhouse effects, environmental pollution, death of soil organisms and marine inhabitants, ozone layer depletion, and human diseases. Although high-quality compost may be better and more beneficial to soil, lowquality compost cannot be considered. It must also be safe for people, plants, and the environment. Pathogenic bacteria should not be present in the compost, and foreign materials should be kept to a minimum. Along with improving soil fertility and quality, compost fertilization delivers several other beneficial effects, such as suppression of plant diseases. ${ }^{1-3}$ Beneficial microorganisms in compost might play significant roles in maintaining plant health and productivity. ${ }^{4,5}$ It must have a minimal amount of trace elements and organic pollutants, as well as should be mature and stable. ${ }^{6}$ Composting is discouraged by pathogens, nutrient deficiency, time-consuming procedures, and odours. Therefore, compost does not yet offer many advantages over other soil-fertilizing sources, including lack of knowledge about microbial activity. A comprehensive literature review is very essential if the end goal is providing solutions for all the above-mentioned challenges to a wide range of populations including the common people, farmers and researchers. The present review article aims to collect information from the existing literature and compile all the collected data for the solutions made possible Under One Roof.

\section{Components of composting}

aerobically and anaerobically. In aerobic composting, organic compounds are oxidized to carbon dioxide, nitrites and nitrates by aerobic microorganisms. The mass temperature rises due to exothermic reactions and facilitates the degradation process. During the anaerobic process, the organic compounds are broken down by anaerobic microorganisms through reduction while metabolism is going on. The least amount of energy is released and the temperature of the decaying mass does not rise much during this process.

Green vegetable waste, a combination of food waste, animal bedding and manure and straw, dairy waste, cow dung, organic fertilizer waste, municipal solid waste, agriculture waste could make good compost depending on their content. Currently, solid organic wastes (SOW), such as MSW (municipal solid waste), animal manure, agricultural residues, etc., are disposed of in conventional ways including landfilling or incineration, but these methods are not sustainable due to limited space. ${ }^{7}$ Green waste (GW) is a common source for composting that is converted to nutrient-rich humus, used to improve the quality of soils. ${ }^{8}$ Comparatively, green waste composting is a very slow process since its main constituents are slowly degradable compounds. Since lignocellulosic material makes up such a large part of green waste, ${ }^{9}$ it is necessary to add some additives to enhance the decomposition rate. There are varieties of additives used for this purpose: coal fly ash, ${ }^{10}$ biochar and animal dung, ${ }^{11}$ and sewage sludge. ${ }^{12}$ Eggshells and their membranes are considered good sources of fertilizer due to their availability. ${ }^{13}$ The role of these shells in compost as a stabilizing agent is well known as it provides negatively charged components like carbonates and glycosaminoglycans. ${ }^{14}$ Rice husk is abundantly produced in rice mills of China and other riceproducing countries enhance the composting process as additive. ${ }^{15}$ Another study had explained how the particle-size distribution influences bulk density, the permeability of compost to water and air, and compost maturity. ${ }^{16}$ Small particles in compost adversely affect its porosity while the presence of very large particles reduces water retention. All of the above additives have a significant impact on the microbial communities. Composting can be carried out both 


\section{Different types of composting processes}

- On-site composting: Recycling of household wastes that include residual cooked/uncooked food, grasses and leaves from garden and papers etc. need a small space and minimum attention. It is widely used in homes.

- Vermicomposting: Use of soil invertebrates such as earthworms, red wigglers etc. for eating and breaking down the waste materials in the compost pile into fertilizers.

- Windrow composting: It is prepared in a comparatively larger space in a form of long thin piles of wind-rows. Sometimes it is prepared in open air space. But when under shelter it has to be aerated by the use of cooling machines.

- In-vessel composting: In this method, an enclosed large container is used which is connected with various electrical controlling systems for proper adjustment of temperature, aeration and turning skills etc.

\section{Microbial ecology of composting}

Effective Microorganism (EM) compost is a bio-organic fertilizer prepared by a combination of microorganisms, which stimulates plant growth and soil fertility. A group of microorganisms referred to as "friendly microbes" was proposed by Professor Teruo Higa, of the University of Ryukyus in Okinawa, Japan. ${ }^{20}$ As described by Friedrich, M. $\mathrm{W}$. Composting is a natural process characterized by microbial community transitions that actively decompose materials under humidity, self-heating and aerobic conditions. ${ }^{21}$ The microbial extract of compost was found to be effective in promoting plant growth and suppressing fungal diseases. ${ }^{22}$

However, exogenous microbes are added in order to accelerate the biodegradation rate by the indigenous microbial community in compost piles. Inoculating with selected microbes artificially could improve the degree of humification and maturation processes. ${ }^{23}$ Both bacteria and fungi play an important role in the representation of microbial community structure during the composting process. The entire process gets affected either negatively or positively by the presence of both bacteria and fungi. There are two important processes involved in composting that are commonly studied; Characterization of microbial activities \& Conversion of organic material.
The microbial functions in the Aerobic Digestion process

Aerobic composting is a commonly used technique to produce organic fertilizer from agricultural waste which happens in the presence of oxygen. This is an effective way to utilize this resourceful waste product.

Aerobic fermentation is a process that involves aerobic microbes (bacteria, actinomycetes, fungi, etc.) that can oxidize organic compounds in fermentation substrates to provide the energy needed for biological growth. This process is accomplished under appropriate conditions such as ventilation, oxygen supply, temperature, moisture content, $\mathrm{pH}$ value, $\mathrm{CO} 2 / \mathrm{N}$ ratio, particle size, etc.

The microbial functions in the Anaerobic Digestion process

A major part of anaerobic digestion (AD) depends on microbial activity; factors such as syntrophic relationships between microbes and delicate balances among them are considered for this process to function effectively. ${ }^{24}$

Anaerobic digestion generally consists of four consecutive stages of bio methanogenesis, namely hydrolysis, acidogenesis, acetogenesis and methanogenesis; the first three stages are mediated by bacteria and the last stage is accomplished by archaea. ${ }^{25}$

\section{Hydrolysis}

During hydrolysis, the first stage of Anaerobic Digestion, fermentative bacteria break down complex organic matter, including carbohydrates, proteins, and lipids into soluble and biodegradable components such as monosaccharides, amino acids, higher fatty acids, and alcohols.

Fermentative bacteria contain extracellular enzymes called cellulases, lipases, and proteases. These enzymes start the degradation process and increase the bioavailability of organic matter in the bacteria's cells. ${ }^{26}$ Among the common hydrolytic fermentative bacteria that are found in anaerobic digestion are Firmicutes, Bacteroidetes, Actinobacteria, Proteobacteria, and Chloroflexi. ${ }^{27}$ Acidogenesis

Most common fermentative bacteria such as Firmicutes, Bacteroidetes, Enterobacter, and Clostridium are playing a major role in the acidogenic phase. Most probably the fermentation 
and metabolization of hydrolyzed products are continued by these acid forming microorganisms which leads towards short-chain volatile fatty acids (VFAs) and alcohols including acetic acid, propionic acid, butyric acid, valeric acid ethanol. ${ }^{28}$

As a result of their spores, these bacteria secrete lytic enzymes to degrade organic matter and are capable of living in extreme conditions and environment. $^{29}$

\section{Acetogenesis}

In acetogenesis, soluble organic acids from hydrolysis and acidogenesis are converted into acetate, hydrogen, and carbon dioxide by acetogenic bacteria. ${ }^{30}$ These microorganisms reduce the $\mathrm{H}_{2}$ and $\mathrm{CO}_{2}$ into acetate. While both compounds are oxidized by the syntrophic acetate-oxidizing bacteria (SAOB). Generally, the acetogenic and SAOB belong to genera Clostridium and Acetobacterium (phylum: Firmicutes). ${ }^{31}$

\section{Methanogenesis}

Methanogenic archaea reduce $\mathrm{CO}_{2} /$ $\mathrm{H}_{2}$, acetate, and methylated compounds to methane in the last phase of anaerobic digestion. As a result, acetate is split into methyl groups and $\mathrm{CO}_{2}$ by aceticlastic methanogens, and the methyl groups are reduced to methane. Hydrogenotrophic methanogens produce methane through reduced $\mathrm{CO}_{2}$ as the source of carbon and energy. ${ }^{32}$ Methanosaeta, Methanobacterium, and Methanosarcinaceae are commonly detected in methanogenesis processes. ${ }^{33}$

Determination of compost maturity and longevity

The functional biodiversity of soils will be assessed by assessing the microbial communities because they are ubiquitous, dominant and active. In terms of biomass, structure/diversity, and activity, they are vital to the functioning of ecosystems and provide services to customers. ${ }^{34}$ In the first phase of microbial activity, the decomposition process begins with the increase in temperature through the oxidation of organic matter. The organic residue stability is increased by the decomposition efficiency of biodegradable materials. The presence of some specifically selected microorganisms can shorten the composting time, accelerate the biodegradation and transformation of organic matter, and improve the efficiency of composting i.e. influencing the maturity of the compost. ${ }^{35} \mathrm{~A}$ variety of microbiota communities can occur during composting depending on the temperature, $\mathrm{C} / \mathrm{N}$ ratio, moisture level, and type of organic components. ${ }^{36}$ During this process, pathogens, herbs and plant toxins and some unprofitable microbial species are eliminated with the addition of a new functional bacterial community in a phenomenon of selfpurification. In a study performed by ${ }^{37}$ the diversity of microbial communities were observed in different days of composting and it was found that the microbial species would change with various stages of the composting process. A study reported the presence of Bacteroidetes and Proteobacteria phylum in raw material of activated sludge which was changed distinctly during the composting process. ${ }^{38}$ Initial stages are predominated by protein and amino acid degrading Bacteria such as Firmicutes, ${ }^{39}$ whereas the Bacteroides are responsible for hydrolyzation of high molecular weight polysaccharides and degradation of lignocelluloses. ${ }^{40}$

Thus, the maturity of the compost is correlated with the microbial activities in the compost. The microbial activity can be determined by studying the microbial metabolic activities, observing the colony-forming units (CFU) and the concentration of composting constituents. ${ }^{41}$ Microorganisms like bacteria and fungi can switch organic waste to humus and improve the physical, chemical and biological properties of the soil. ${ }^{42}$ It was found that Proteobacteria, Bacteroidetes, Firmicutes, Actinobacteria, Chloroflexi, and Planctomycetes were the dominant phyla in the passive ventilation composting process of dairy manure, and significant changes were observed between these phyla at the four stages of composting. ${ }^{35}$ Pseudomonas, Acinetobacter, Steroidobacter, Bacillus and Sphingobacterium were the most abundant genera in rice straw, sugar cane bagasse, and coffee hull composting processes with cow manure additions. ${ }^{43}$ Ureibacillus, Tepidimicrobium, Kribbella and Bordetella were reported to be the dominant genera in sludge and cattle dung composting. ${ }^{44}$ Sporosarcina, Bacillus, Cellvibrio, Devosia and Cellulomonas were the most abundant genera in the maize straw composting process. ${ }^{45}$

Overall, a diverse variety of microbial communities are involved in the composting process. Bacteria from the genera Anthrobacter, Bacillus, Enterobacter, Escherichia, Micrococcus, 
Morganella, Nitrobacter, Proteus, Pseudomonas, Staphylococcus, Humicola, Penicillium, Rhizopus, Sordarla and Trichurus have been found to be associated with composting processes as observed by various researchers. ${ }^{46}$

The development of new molecular approaches called -Omics have recently allowed the characterization of the overall microbial genetic and functional diversity through the high throughput analysis of DNAs (genomics), RNAs (transcriptomics), proteins (proteomics), enzymes activities (enzymomics) or metabolites (metabolomics). ${ }^{47}$ In particular, the advent of next-generation sequencing techniques, such as complete genome shotgun sequencing, highthroughput sequencing and single-molecule longread sequencing, has allowed the identification of the microorganism communities present in the soil. By applying different -Omic approaches to the same target, microbial community diversity can be linked to ecological processes, ecosystem services and potentially food quality. In this regard-Omics approaches can help to further understand the link between soil microbial diversity, its community composition and abundance, and ecological functions provided; hence, highlighting the benefit of ecological intensification.

Presence of pathogenic microbes in compost

Inadequately handled compost may be a disease source in the environment. Reports in municipal wastes, sewage sludges and other organic sludge found to contain a number of harmful pathogens. ${ }^{54}$ Sewage sludge is generally richer in pathogens than municipal solid waste. ${ }^{55}$ Pathogens found in composting can be viruses, bacteria, protozoa or helminths especially when the components are municipal solids waste and sewage sludge. Thus, along with providing nutrients and beneficial microorganisms, the organic fertilisers may sometimes be seen to spread pathogenic microorganisms into agroecosystems. ${ }^{56-58}$ In certain anaerobic composting systems presence of common pathogens such as Salmonella, Clostridium, Campylobacter, Listeria monocytogenes and Escherichia coli were found during early phases. . $^{5,60}$ It is also suggested that the thermophilic phase of composting is responsible for killing the pathogens. $^{61}$
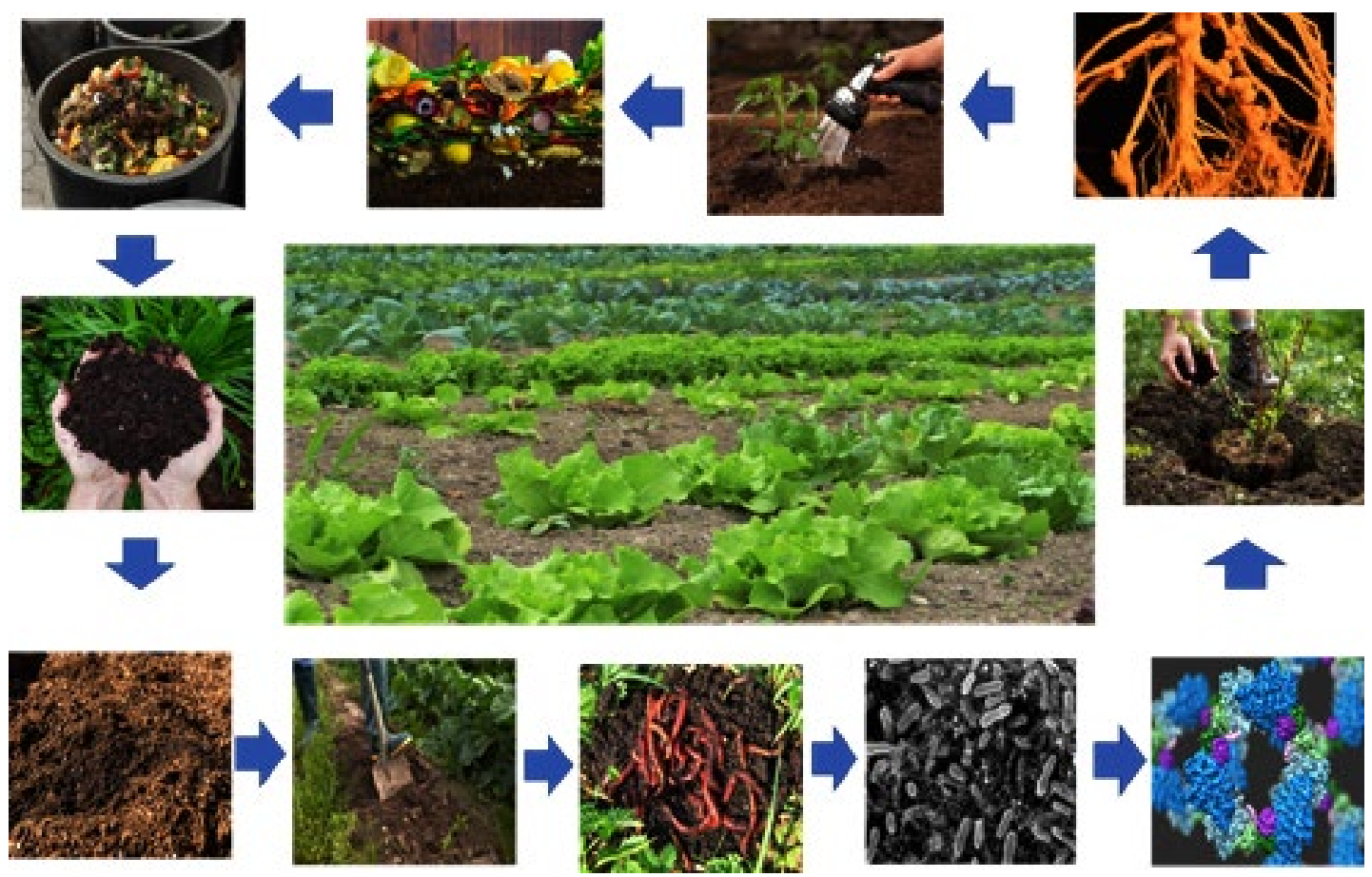

Fig. 1. Microbial Way of composting. 
The enteric pathogen is known to be able to grow even after having diminished below the detectable limits thus representing a health hazard for certain uses of compost. The most critical factor to prevent the regrowth of pathogens is to provide stability. The compost materials appear to be stable when their dryness supports high rates of beneficial microbial work. When this compost material is rewetted, pathogens can repopulate in certain conditions. ${ }^{62}$ Therefore, it is always safe to store compost products under dry conditions. ${ }^{63}$ Reports show that industrial biowastes composts are safely commercialized as products within 4 to 6 months. ${ }^{64}$ Thus, the long-term duration storage for composting should be avoided to prevent the survival and regrowth of pathogens. However, proper management of the thermophilic microbes and mature stages of the composting process remains an important step in controlling the persistence of pathogens.

Plant growth-promoting microorganisms in the rhizosphere

Plants growth in farming soils is affected by various biotic and abiotic factors. The rhizosphere is a thin layer of soil that instantly covers the plant roots where various metabolic activities of roots are observed. The rhizosphere is home to a diverse range of microorganisms, including bacteria,

Table 1. Microbial diversity studies using omics approaches

\begin{tabular}{|c|c|c|c|}
\hline No. & Molecular Technique & Reported Organisms & Author and year \\
\hline 1. & Metabolomics & $\begin{array}{l}\text { Mycorrhizal fungi (AMF), } \\
\text { Endophytic fungi }\end{array}$ & $\begin{array}{l}\text { Bernardo L, Carletti P, Badeck FW, } \\
\text { et } \mathrm{al}^{49}\end{array}$ \\
\hline 2. & $\begin{array}{l}16 \mathrm{~S} \text { rDNA gene } \\
\text { pyrosequencing }\end{array}$ & Bacteria & $\begin{array}{l}\text { Dal Cortivo C, Ferrari M, Visioli G, } \\
\text { et } a^{50}\end{array}$ \\
\hline 3. & $\begin{array}{l}\text { high-throughput pyrosequencing } \\
\text { of bacterial 16SV1-V3 and fungal } \\
\text { ITS2 of the ribosomal DNA operon }\end{array}$ & Bacteria and fungi & $\begin{array}{l}\text { (Hartmann M, Frey B, Mayer J, } \\
\text { Mader P, Widmer F }{ }^{51}\end{array}$ \\
\hline 4. & 16S rDNA V3 region gene sequence & Rhizospheric Bacteria & $\begin{array}{l}\text { (Visioli G, Sanangelantoni AM, } \\
\text { Vamerali T, Dal Cortivo C, } \\
\text { Blandino } \mathrm{M}^{52}\end{array}$ \\
\hline 5. & $\begin{array}{l}\text { RT-PCR and pyrosequencing of } \\
16 \mathrm{~S} \text { rDNA gene }\end{array}$ & Bacteria and archaea & $\begin{array}{l}\text { (Pershina E, Valkonen J, } \\
\text { Kurki P, et al }{ }^{53}\end{array}$ \\
\hline
\end{tabular}

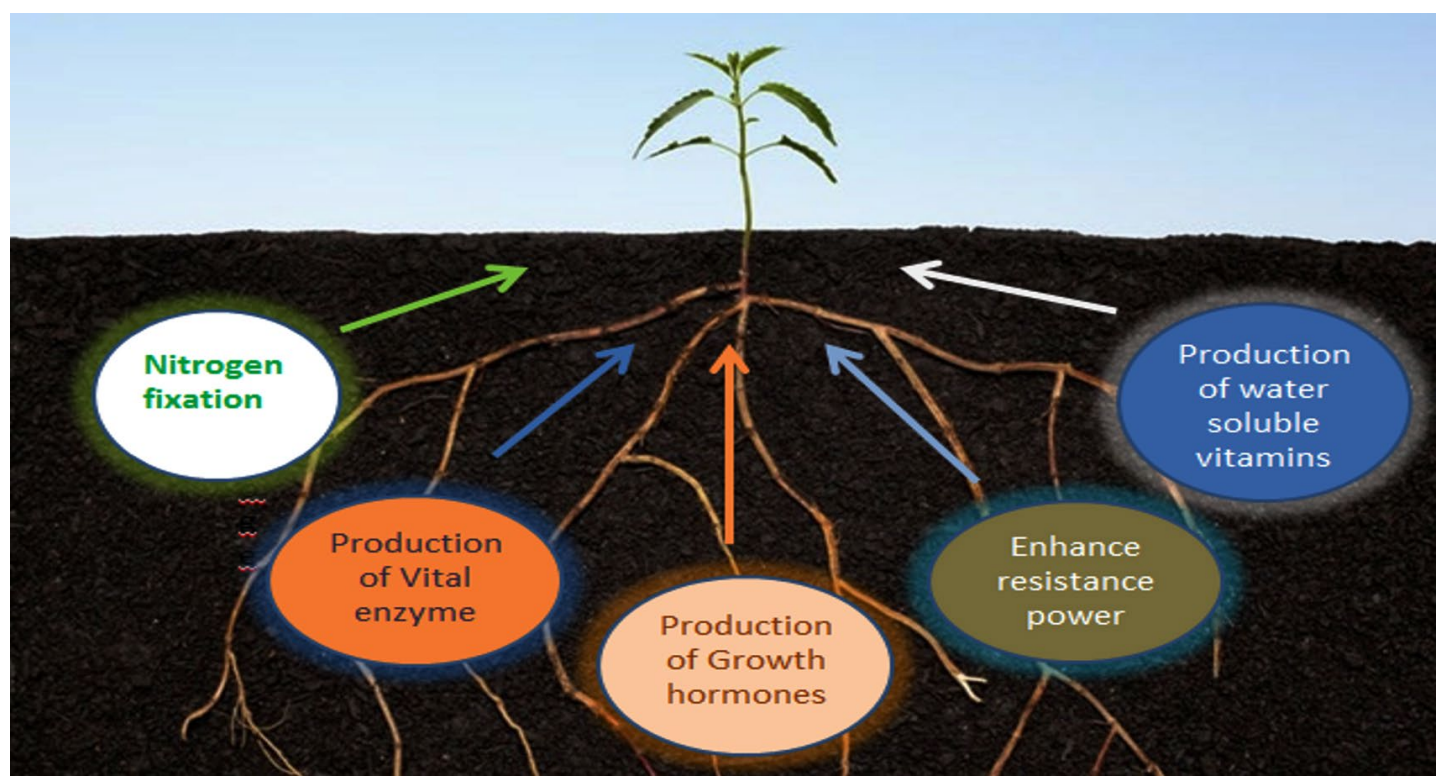

Fig. 2. Mechanism of PGPR. 
fungus, protozoa, and algae. ${ }^{65,66}$ Pseudomonas, Azospirillum, Azotobacter, Klebsiella, Enterobacter, Anthrobacter bacillus and Serratia are some microorganisms that have enormous plant growth-inducing capacity. ${ }^{67}$ Mechanism of induction of systematic resistance and production of siderophores or antibiotics keep the bacteria to suppress the plant diseases. The use of plant growth-promoting rhizobacteria replaces the use of pesticides, chemical fertilizers and supplements resulting in significant growth in height of the plant, length of root, dry matter production of shoot and root of plants. Potato, radish, sugar beet and sweet potato cultivations are getting benefits out of this. ${ }^{68}$

Many recent studies have also evidenced the detailed mechanism through which plant growth-promoting rhizobacteria (PGPR) greatly revitalizes the soil condition and plant health, and enhances crop yield in agriculture. Apart from the removal of harmful pathogenic microorganisms, plant growth-promoting rhizobacteria provide an appropriate environment for plant nutrition and root growth. This rhizobacteria not only help in nitrogen fixation providing plants with the absorbable form of ammonia but also produce important factors like siderophores, phytohormones such as cytokinins, gibberellins, etc. Phosphate solubilization and mineralization of organic compounds, production of phytohormones (biofertilizers) like IAA, abscisic acid (ABA), ethylene (ET), and auxins, and nitrogen fixation are also some important plant growth-promoting rhizobacterial activities. ${ }^{69-72}$ However, the effect of the microbial community of compost on rhizosphere microbial activity needs to be elucidated extensively which could be a very promising subject of research. It can also be effective to use this rhizobacteria as an exogenous inoculum for developing compost. Microbial content associated with earthworms

Earthworms play a major role in shaping soil structure format and cycling nutrients. ${ }^{73}$ They also help in maintaining a healthy soil ecosystem and are known as ecosystem engineers. ${ }^{74}$ Vermicomposting effectively reduces organic biomass and generates high-quality fertilizer for plants. Works are being done to study bacterial communities residing in the gut of earthworms that are involved in this decomposition process. Another experiment observed that vermicomposting increases the taxonomic diversity of bacterial communities accompanied by an increase in their functional diversity as well as metabolic capacity and other plant growth promoting factors. ${ }^{75}$ Depending on their effects on the soil compartment and microbial communities, earthworms can be categorized into three types of ecological groups. Such as; epigeic earthworms are found on the surface of the soil and feed on organic litter, endogeic earthworms produce horizontal tunnels when they feed on mineral soil and partially decomposed materials and anecic earthworms are the largest species that survive on the nutrients obtained from the microorganisms present in the dead and degrading organic matters and deposit their casts at the entrance of the burrows. ${ }^{76,77}$ Activities of microorganisms present in the soil are known to be controlled by earthworms. ${ }^{78}$ The relationship between earthworm and soil microorganisms is very complex which is considered as the 'sleeping beauty paradox'. ${ }^{79}$ The microorganisms in soil normally stay dormant and get activated in the presence of suitable environmental conditions, earthworms being considered as an important activator. They have a direct and important role in increasing the soil microorganisms through providing digested nutrition products and by dropping down the microbial biomass from their gut in the form of casts. ${ }^{80,81}$ According to a report the endogenic $A$ trapezoides had no effect on the numerical form of soil bacterial operational taxonomic units. ${ }^{82}$ Another report observed the positive effect of earthworms on the bacterial richness and their diversity which were created by four epi-anaeic species from the genus Lumbricus. ${ }^{83}$ In the study of vermicomposting methods, the importance of earthworms on soil microbial diversity had been investigated. During the first stage of vermicomposting, the earthworms of epigeic group Eudrilus sp. and $E$. fetida increased the bacterial diversity on the substrate. ${ }^{84}$ However, the negative effects of earthworms on bacterial richness were explained by the reduced number of bacterial species during the passage through Eisenia's gut and of $L$. rubellus as observed in the casts. ${ }^{85}$ The interaction between earthworms and microorganisms during soil nutrient cycling and many other important pollutants leaves us with limited knowledge about 
its mechanism. Next-generation sequencing (NGS) could be used profoundly to achieve the solution in the near future. ${ }^{77}$

\section{CONCLUSION}

Improper waste management leads to an unsafe environment which ought to be replaced with composting like safer waste management. The world is leading towards a changed natural resource where human impact on and adjustment to the physical environment is inevitable. The composting process can play an important role in achieving this goal as organic fertilizer. The importance of composting will cause less use of industry made chemical fertilizers in favour of natural compost. By decreasing the number of harmful chemicals discharged into the environment through decreasing their usage, it would undoubtedly benefit the environment and human health. Much more awareness of the potential of technology is still needed for farmers to fully contain it. To make plant compost effective against nematodes, compost could be supplemented with bactericides and fungicides. More research is needed to understand materials that need to be composted for a long time and those that are gradually being mineralized. A study is also needed to determine the effect of interaction between various sources of microbial communities assembled in soil; from plant rhizosphere, earthworm cast and mature compost.

\section{ACKNOWLEDGMENTS}

None.

\section{CONFLICT OF INTEREST}

The authors declare that there is no conflict of interest

\section{AUTHORS' CONTRIBUTION}

KD conceptualized the work. PPR helped in data collection, analysis and interpretation. KD, PPR and SP helped in manuscript preparation, drafting the manuscript and its critical revision. All authors read and approved the final manuscript for publication.

\section{FUNDING}

None.

\section{DATA AVAILABILITY}

All datasets generated during the current study are available from the corresponding author on reasonable request.

\section{ETHICS STATEMENT}

Not applicable.

\section{REFERENCES}

1. Hadar Y, Papadopoulou KK. Suppressive composts: microbial ecology links between abiotic environments and healthy plants. Annu Rev Phytopathol. 2012;50:133153. doi: 10.1146/annurev-phyto-081211-172914

2. Liu H, Xiong W, Zhang R, et al. Continuous application of different organic additives can suppress tomato disease by inducing the healthy rhizospheric microbiota through alterations to the bulk soil microflora. Plant and Soil. 2018;423(1):229-240. doi: 10.1007/s11104017-3504-6

3. Li H, Cai X, Gong J, Xu T, Ding G chun, Li J. Long-term organic farming manipulated rhizospheric microbiome and Bacillus antagonism against pepper blight (Phytophthora capsici). Front Microbiol. 2019;10:342. doi: 10.3389/fmicb.2019.00342

4. Arif MS, Riaz M, Shahzad SM, et al. Fresh and composted industrial sludge restore soil functions in surface soil of degraded agricultural land. Sci Total Environ. 2018;619:517-527. doi: 10.1016/j. scitotenv.2017.11.143

5. Yu YY, Li SM, Qiu JP, Li JG, Luo YM, Guo JH. Combination of agricultural waste compost and biofertilizer improves yield and enhances the sustainability of a pepper field. J Plant Nutr Soil Sci. 2019;182(4):560-569. doi: 10.1002/jpln.201800223

6. Baffi C, Dell'Abate MT, Nassisi A, et al. Determination of biological stability in compost: A comparison of methodologies. Soil Biol Biochem. 2007;39(6):12841293. doi: 10.1016/j.soilbio.2006.12.004

7. Soobhany N. Preliminary evaluation of pathogenic bacteria loading on organic Municipal Solid Waste compost and vermicompost. J Environ Manage. 2018;206:763-767. doi: 10.1016/j. jenvman.2017.11.029

8. Zhang L, Sun X. Effects of bean dregs and crab shell powder additives on the composting of green waste. Bioresour Technol. 2018;260:283-293. doi: 10.1016/j. biortech.2018.03.126

9. Reyes-Torres M, Oviedo-Ocana ER, Dominguez I, Komilis D, Sanchez A. A systematic review on the composting of green waste: Feedstock quality and optimization strategies. Waste Manag. 2018;77:486499. doi: 10.1016/j.wasman.2018.04.037

10. Awasthi MK, Awasthi SK, Wang Q, et al. Influence of biochar on volatile fatty acids accumulation and microbial community succession during biosolids composting. Bioresour Technol. 2018;251:158-164. doi: 10.1016/j.biortech.2017.12.037

11. Das M, Uppal HS, Singh R, et al. Co-composting of physic nut (Jatropha curcas) deoiled cake with rice straw and different animal dung. Bioresour 
Technol. 2011;102(11):6541-6546. doi: 10.1016/j. biortech.2011.03.058

12. Guo Y, Rene ER, Wang J, Ma W. Biodegradation of polyaromatic hydrocarbons and the influence of environmental factors during the co-composting of sewage sludge and green forest waste. Bioresour Technol. 2020;297:122434. doi: 10.1016/j. biortech.2019.122434

13. Roy M, Mohanty K. Valorization of waste eggshellderived bioflocculant for harvesting T. obliquus: process optimization, kinetic studies and recyclability of the spent medium for circular bioeconomy. Bioresour Technol. 2020;307:123205. doi: 10.1016/j. biortech.2020.123205

14. Soares MA, Quina MJ, Quinta-Ferreira R. Influence of $\mathrm{N}$-rich material in valorization of industrial eggshell by co-composting. Environ Technol. 2016;37(21):27732785. doi: $10.1080 / 09593330.2016 .1164251$

15. Ahmad A, Khan N, Giri BS, Chowdhary P, Chaturvedi P. Removal of methylene blue dye using rice husk, cow dung and sludge biochar: Characterization, application, and kinetic studies. Bioresour Technol. 2020;306:123202. doi: 10.1016/j. biortech.2020.123202

16. Martin-Rios C, Demen-Meier C, Gossling S, Cornuz C. Food waste management innovations in the foodservice industry. Waste Manag. 2018; 79:196206. doi: 10.1016/j.wasman.2018.07.033

17. Ramnarain YI, Ansari AA, Ori L. Vermicomposting of different organic materials using the epigeic earthworm Eisenia foetida. Int J Recycl Org Waste Agric. 2019;8(1):23-36. doi: 10.1007/s40093-0180225-7

18. Aziz SQ, Omar IA, Mustafa JS. Design and study for composting process site. Int J Eng Invent. 2018;7(9):0918.

19. Lim LY, Bong CPC, Lee CT, Klemes JJ, Sarmidi MR, Lim JS. Review on the current composting practices and the potential of improvement using two-stage composting. Chem Eng Trans. 2017;61:1051-1056. doi: 10.3303/ CET1761173

20. Singh S, Singh V, Pal K. Importance of microorganisms in agriculture. Climate and Environmental changes: Impact, Challenges and Solutions. 2017;1:93-117.

21. Palaniveloo K, Amran MA, Norhashim NA, et al. Food waste composting and microbial community structure profiling. Processes. 2020;8(6):723. doi: 10.3390/ pr8060723

22. Zouari I, Masmoudi F, Medhioub K, Tounsi S, Trigui M. Biocontrol and plant growth-promoting potentiality of bacteria isolated from compost extract. Antonie Van Leeuwenhoek. 2020;113(12):2107-2122. doi: 10.1007/ s10482-020-01481-8

23. Wei Z, Xi B, Zhao Y, Wang S, Liu H, Jiang Y. Effect of inoculating microbes in municipal solid waste composting on characteristics of humic acid. Chemosphere. 2007;68(2):368-374. doi: 10.1016/j. chemosphere.2006.12.067

24. Song L, Song Y, Li D, Liu R, Niu Q. The auto fluorescence characteristics, specific activity, and microbial community structure in batch tests of mono-chicken manure digestion. Waste Management. 2019;83:57-
67. doi: 10.1016/j.wasman.2018.11.002

25. Nguyen $A Q$, Wickham R, Nguyen LN, et al. Impact of anaerobic co-digestion between sewage sludge and carbon-rich organic waste on microbial community resilience. Environmental Science: Water Research \& Technology. 2018;4(12):1956-1965. doi: 10.1039/ C8EW00663F

26. Westerholm M, Schnürer A. Microbial responses to different operating practices for biogas production systems. Anaerobic Digestion. 2019:1-36. doi: 10.5772/intechopen.82815

27. Luo X, Yuan X, Wang S, et al. Methane production and characteristics of the microbial community in the co-digestion of spent mushroom substrate with dairy manure. Bioresour Technol. 2018;250:611-620. doi: 10.1016/j.biortech.2017.11.088

28. Ur-Rehman ML, Iqbal A, Chang CC, Li W, Ju M. Anaerobic digestion. Water Environment Research 2019;91(10):1253-1271. doi: 10.1002/wer.1219

29. Mahdy A, Wandera SM, Bi S, Song Y, Qiao W, Dong $R$. Response of the microbial community to the methanogenic performance of biologically hydrolyzed sewage sludge with variable hydraulic retention times. Bioresour Technol. 2019;288:121581. doi: 10.1016/j. biortech.2019.121581

30. Bajpai P. Basics of anaerobic digestion process. In: Anaerobic Technology in Pulp and Paper Industry. Springer; 2017:7-12. doi: 10.1007/978-981-10-41303_2

31. Kim E, Lee J, Han G, Hwang S. Comprehensive analysis of microbial communities in full-scale mesophilic and thermophilic anaerobic digesters treating food wasterecycling wastewater. Bioresour Technol. 2018;259:442450. doi: 10.1016/j.biortech.2018.03.079

32. Ventorino V, Romano I, Pagliano G, Robertiello A, Pepe O. Pre-treatment and inoculum affect the microbial community structure and enhance the biogas reactor performance in a pilot-scale biodigestion of municipal solid waste. Waste Management. 2018;73:69-77. doi: 10.1016/j.wasman.2017.12.005

33. Tian $H$, Fotidis IA, Mancini E, et al. Acclimation to extremely high ammonia levels in continuous biomethanation process and the associated microbial community dynamics. Bioresour Technol. 2018;247:616623. doi: 10.1016/j.biortech.2017.09.148

34. Roy K, Ghosh D, DeBruyn JM, et al. Temporal dynamics of soil virus and bacterial populations in agricultural and early plant successional soils. Front Microbiol. 2020;11:1494. doi: 10.3389/fmicb.2020.01494

35. Zhong XZ, Ma SC, Wang SP, et al. A comparative study of composting the solid fraction of dairy manure with or without bulking material: performance and microbial community dynamics. Bioresour Technol. 2018;247:443-452. doi: 10.1016/j. biortech.2017.09.116

36. Azim K, Soudi B, Boukhari S, Perissol C, Roussos S, Alami IT. Composting parameters and compost quality: a literature review. Org Agric. 2018;8(2):141-158. doi: 10.1007/s13165-017-0180-z

37. Che J, Lin W, Ye J, et al. Insights into compositional changes of dissolved organic matter during a fullscale vermicomposting of cow dung by combined 
spectroscopic and electrochemical techniques. Bioresour Technol. 2020;301:122757. doi: 10.1016/j. biortech.2020.122757

38. Yu Z, Tang J, Liao $\mathrm{H}$, et al. The distinctive microbial community improves composting efficiency in a full-scale hyperthermophilic composting plant. Bioresour Technol. 2018;265:146-154. doi: 10.1016/j. biortech.2018.06.011

39. Ma S, Xiong J, Cui R, et al. Effects of intermittent aeration on greenhouse gas emissions and bacterial community succession during large-scale membrane-covered aerobic composting. J Clean Prod. 2020;266:121551. doi: 10.1016/j.jclepro.2020.121551

40. Guo H, Gu J, Wang X, et al. Beneficial effects of bacterial agent/bentonite on nitrogen transformation and microbial community dynamics during aerobic composting of pig manure. Bioresour Technol. 2020;298:122384. doi: 10.1016/j. biortech.2019.122384

41. Cesaro A, Conte A, Belgiorno V, Siciliano A, Guida M. The evolution of compost stability and maturity during the full-scale treatment of the organic fraction of municipal solid waste. J Environ Manage. 2019;232:264-270. doi: 10.1016/j.jenvman.2018.10.121

42. Pant AP, Radovich TJ, Hue NV, Paull RE. Biochemical properties of compost tea associated with compost quality and effects on pak choi growth. Sci Hortic. 2012;148:138-146. doi: 10.1016/j.scienta.2012.09.019

43. de Gannes V, Eudoxie G, Hickey WJ. Prokaryotic successions and diversity in composts as revealed by 454-pyrosequencing. Bioresour Technol. 2013;133:573580. doi: 10.1016/j.biortech.2013.01.138

44. Lv B, Xing M, Yang J, Zhang L. Pyrosequencing reveals bacterial community differences in composting and vermicomposting on the stabilization of mixed sewage sludge and cattle dung. Appl Microbiol Biotechnol. 2015;99(24):10703-10712. doi: 10.1007/s00253-0156884-7

45. Wei H, Wang L, Hassan M, Xie B. Succession of the functional microbial communities and the metabolic functions in maize straw composting process. Bioresour Technol. 2018;256:333-341. doi: 10.1016/j. biortech.2018.02.050

46. Kor YY, Prabhu J, Esposito M. How large food retailers can help solve the food waste crisis. Harv. Bus. Rev. 2017;19

47. Bouchez $T$, Blieux AL, Dequiedt $S$, et al. Molecular microbiology methods for environmental diagnosis. Environ Chem Lett. 2016;14(4):423-441. doi: 10.1007/ s10311-016-0581-3

48. Bernardo L, Carletti P, Badeck FW, et al. Metabolomic responses triggered by arbuscular mycorrhiza enhance tolerance to water stress in wheat cultivars. Plant Physiol Biochem. 2019;137:203-212. doi: 10.1016/j. plaphy.2019.02.007

49. Bonini $P$, Rouphael $Y$, Miras-Moreno B, et al. A microbial-based biostimulant enhances sweet pepper performance by metabolic reprogramming of phytohormone profile and secondary metabolism. Front Plant Sci. 2020;11:567388. doi: 10.3389/ fpls.2020.567388

50. Dal Cortivo C, Ferrari M, Visioli G, et al. Effects of seed- applied biofertilizers on rhizosphere biodiversity and growth of common wheat (Triticum aestivum L.) in the field. Front Plant Sci. 2020;11:72. doi: 10.3389/ fpls.2020.00072

51. Hartmann M, Frey B, Mayer J, Mader P, Widmer F. Distinct soil microbial diversity under long-term organic and conventional farming. The ISME Journal. 2015;9(5):1177-1194. doi: 10.1038/ismej.2014.210

52. Visioli G, Sanangelantoni AM, Vamerali T, Dal Cortivo C, Blandino M. 16S rDNA profiling to reveal the influence of seed-applied biostimulants on the rhizosphere of young maize plants. Molecules. 2018;23(6):1461. doi: 10.3390/molecules23061461

53. Pershina E, Valkonen J, Kurki P, et al. Comparative analysis of prokaryotic communities associated with organic and conventional farming systems. PLOS One. 2015;10(12):e0145072. doi: 10.1371/journal. pone. 0145072

54. Bustamante MA, Moral R, Paredes C, Vargas-Garcia MC, Suarez-Estrella F, Moreno J. Evolution of the pathogen content during co-composting of winery and distillery wastes. Bioresour Technol. 2008;99(15):7299-7306. doi: 10.1016/j.biortech.2007.12.051

55. Insam H, De Bertoldi M. Microbiology of the composting process. In: Waste Management Series. Elsevier. 2007;8:25-48. doi: 10.1016/S1478-7482(07)80006-6

56. Avery LM, Booth P, Campbell C, Tompkins D, Hough $\mathrm{RL}$. Prevalence and survival of potential pathogens in source-segregated green waste compost. Sci Total Environ. 2012;431:128-138. doi: 10.1016/j. scitotenv.2012.05.020

57. Zhu YG, Johnson TA, Su JQ, et al. Diverse and abundant antibiotic resistance genes in Chinese swine farms. Proc Natl Acad Sci. 2013;110(9):3435-3440. doi: 10.1073/pnas.1222743110

58. Chen Z, Jiang X. Microbiological safety of chicken litter or chicken litter-based organic fertilizers: a review. Agriculture. 2014;4(1):1-29. doi: 10.3390/ agriculture4010001

59. Ferens WA, Hovde CJ. Escherichia coli O157: H7: animal reservoir and sources of human infection. Foodborne Pathog Dis. 2011;8(4):465-487. doi: 10.1089/ fpd.2010.0673

60. Manyi-Loh CE, Mamphweli SN, Meyer EL, Makaka G, Simon M, Okoh Al. An overview of the control of bacterial pathogens in cattle manure. Int J Environ Res Public Health. 2016;13(9):843. doi: 10.3390/ ijerph13090843

61. Froschle B, Messelhausser U, Holler C, Lebuhn M. Fate of Clostridium botulinum and incidence of pathogenic clostridia in biogas processes. J Appl Microbiol. 2015;119(4):936-947. doi: 10.1111/jam.12909

62. Wilkinson KG. The biosecurity of on-farm mortality composting. J Appl Microbiol. 2007;102(3):609-618. doi: 10.1111/j.1365-2672.2006.03274.x

63. Bohm R. Pathogenic agents. In: Waste Management Series. Elsevier. 2007;8:177-200. doi: 10.1016/S14787482(07)80012-1

64. Lemunier M, Francou C, Rousseaux S, et al. Long-term survival of pathogenic and sanitation indicator bacteria in experimental biowaste composts. Appl Environ Microbiol. 2005;71(10):5779-5786. doi: 10.1128/ 


\section{AEM.71.10.5779-5786.2005}

65. Antoun $\mathrm{H}$. Plant-growth-promoting rhizobacteria. Brenner's Encycl Genet 2 ${ }^{\text {nd }}$ Ed. 2013:353-355. doi: 10.1016/B978-0-12-374984-0.01169-4

66. Barriuso J, Solano BR, Lucas JA, Lobo AP, GarciaVillaraco A, Manero FJG. Ecology, genetic diversity and screening strategies of plant growth promoting rhizobacteria (PGPR). J Plant Nutr. 2008;4:1-17. doi: 10.1002/9783527621989.ch1

67. Joseph B, Patra RR, Lawrence R. Characterization of plant growth promoting rhizobacteria associated with chickpea (Cicer arietinum L.). Int J Plant Prod. 2007;1(2):141-152. doi: 10.22069/IJPP.2012.532

68. Farzana Y, Radziah O, Saad S, Kamaruzaman S. Growth and storage root development of sweetpotato inoculated with rhizobacteria under glasshouse conditions. Aust J Basic App/ Sci. 2009;3(2):1461-1466.

69. Meena M, Swapnil P, Divyanshu K, et al. PGPR-mediated induction of systemic resistance and physiochemical alterations in plants against the pathogens: Current perspectives. J Basic Microbiol. 2020;60(10):828-861. doi: 10.1002/jobm.202000370

70. Dey R, Pal KK, Bhatt DM, Chauhan SM. Growth promotion and yield enhancement of peanut (Arachis hypogaea L.) by application of plant growth-promoting rhizobacteria. Microbiol Res. 2004;159(4):371-394. doi: 10.1016/j.micres.2004.08.004

71. Patten CL, Glick BR. Role of Pseudomonas putida indoleacetic acid in development of the host plant root system. Appl Environ Microbiol. 2002;68(8):3795-3801. doi: 10.1128/AEM.68.8.3795-3801.2002

72. Saleem M, Arshad M, Hussain S, Bhatti AS. Perspective of plant growth promoting rhizobacteria (PGPR) containing ACC deaminase in stress agriculture. J Ind Microbiol Biotechnol. 2007;34(10):635-648. doi: 10.1007/s10295-007-0240-6

73. Blouin M, Hodson ME, Delgado EA, et al. A review of earthworm impact on soil function and ecosystem services. Eur J Soil Sci. 2013;64(2):161-182. doi: 10.1111/ejss.12025

74. Baker G. Differences in nitrogen release from surface and incorporated plant residues by two endogeic species of earthworms (Lumbricidae) in a red-brown earth soil in southern Australia. Eur J Soil Biol. 2007;43:S165-S170. doi: 10.1016/j.ejsobi.2007.08.037

75. Dominguez J, Aira M, Kolbe AR, Gomez-Brandon $M$, Perez-Losada M. Changes in the composition and function of bacterial communities during vermicomposting may explain beneficial properties of vermicompost. Sci Rep. 2019;9(1):9657. doi: 10.1038/ s41598-019-46018-w

76. Thakuria D, Schmidt O, Finan D, Egan D, Doohan FM. Gut wall bacteria of earthworms: a natural selection process. The ISME Journal. 2010;4(3):357-366. doi: 10.1038/ismej.2009.124

77. Medina-Sauza RM, Alvarez-Jimenez M, Delhal A, et al. Earthworms building up soil microbiota, a review. Front Environ Sci. 2019;7:81. doi: 10.3389/fenvs.2019.00081

78. Lavelle $P$, Spain A, Blouin M, et al. Ecosystem engineers in a self-organized soil: a review of concepts and future research questions. Soil Sci. 2016;181(3/4):91-109. doi: $10.1097 /$ SS.0000000000000155

79. Thomas E, Prabha VS, Kurien VT, Thomas AP. The potential of earthworms in soil carbon storage: a review. Environ Exp Biol. 2020;18(2):61-75. doi: 10.22364/eeb.18.06

80. Shan J, Liu J, Wang Y, et al. Digestion and residue stabilization of bacterial and fungal cells, protein, peptidoglycan, and chitin by the geophagous earthworm Metaphire guillelmi. Soil Biol Biochem. 2013;64:9-17. doi: 10.1016/j.soilbio.2013.03.009

81. De Menezes AB, Prendergast-Miller MT, Macdonald LM, et al. Earthworm-induced shifts in microbial diversity in soils with rare versus established invasive earthworm populations. FEMS Microbiol Ecol. 2018;94(5):fiy051. doi: 10.1093/femsec/fiy051

82. Hoeffner K, Monard C, Santonja M, Cluzeau D. Feeding behaviour of epi-anecic earthworm species and their impacts on soil microbial communities. Soil Biol Biochem. 2018;125:1-9. doi: 10.1016/j. soilbio.2018.06.017

83. Gopal M, Bhute SS, Gupta A, et al. Changes in structure and function of bacterial communities during coconut leaf vermicomposting. Antonie Van Leeuwenhoek. 2017;110(10):1339-1355. doi: 10.1007/s10482-0170894-7

84. Koubova A, Chronakova A, Pizl V, Sanchez-Monedero MA, Elhottova D. The effects of earthworms Eisenia spp. on microbial community are habitat dependent. Eur J Soil Biol. 2015;68:42-55. doi: 10.1016/j. ejsobi.2015.03.004

85. Furlong MA, Singleton DR, Coleman DC, Whitman WB. Molecular and culture-based analyses of prokaryotic communities from an agricultural soil and the burrows and casts of the earthworm Lumbricus rubellus. Appl Environ Microbiol. 2002;68(3):1265-1279. doi: 10.1128/AEM.68.3.1265-1279.2002 